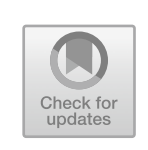

\title{
Biblical Stewardship and Economic Progress
}

\author{
Anne Ratbbone Bradley
}

\section{InTroduction God’s Design ANd Desires}

This paper will be an exploration into the design and desires of God which are revealed to us in the story of creation. When society is constructed in ways that allow human beings to work and unleash their human creativity in God-pleasing ways, human flourishing is advanced. When society is not ordered in ways that both respect the desires of God and the objective realities of creation human flourishing is hindered and stunted. There is a path to human flourishing that requires specific institutions and must respect the principles and realities that economics helps illuminate.

This paper will examine those economic realities from the whole scope and comprehensive narrative of scripture to understand how we can better advance human flourishing around the world. We will begin with a theological attempt to understand God's design and desires for us and his creation, which reveals his purposes and ours. The paper will then discuss how understanding our purpose requires that we live out our purpose which is ordained through our creation (imago dei) through our human creativity as it is applied to nature. The transformation that occurs allows us to fulfill God's creation mandate as it is revealed in Genesis. We then

\footnotetext{
A. R. Bradley $(\bowtie)$

Academic Director, The Fund for American Studies, Washington, DC, USA

(C) The Author(s) 2020

T. Akram and S. Rashid (eds.), Faith, Finance, and Economy, https://doi.org/10.1007/978-3-030-38784-6_3
} 
will assert a biblical perspective of stewardship: oikonomia-prudent stewardship of the gifts and talents which God has endowed each of us with for the purposes of work with the goal of value creation which allows us to make contributions to shalom, or flourishing. The paper will define flourishing theologically and then present the Austrian school of economic thinking as it was particularly developed by Ludwig von Mises and F. A. Hayek as detailing a political economy that is most in line with a world where individuals can pursue and obtain biblical human flourishing.

The creation account detailed in Genesis gives us the divine context for our existence. We are not here by chance. We are formed by the creative imagination and hand of God, made in his image and likeness (Genesis 1:25-28). We are here precisely because God put us here. This reality instills great dignity, purpose, and immeasurable value within us. Genesis 1:25-28 informs us both about the nature of God and the nature of mankind:

God made the wild animals according to their kinds, the livestock according to their kinds, and all the creatures that move along the ground according to their kinds. And God saw that it was good. Then God said, "Let us make mankind in our image, in our like- ness, so that they may rule over the fish in the sea and the birds in the sky, over the livestock and all the wild animals, and over all the creatures that move along the ground." So God created mankind in his own image, in the image of God he created them; male and female he created them. God blessed them and said to them, "Be fruitful and increase in number; fill the earth and subdue it. Rule over the fish in the sea and the birds in the sky and over every living creature that moves on the ground."

What does it mean to be created in God's image? In Systematic Theology, Wayne Grudem points out that the words used in Genesis 1:26-27, "image" (tselem) and "likeness" (demut), in the Hebrew "refer to something that is similar but not identical to the thing that it represents or is the 'image' of." Genesis 1:26 "would have meant to the original readers, 'Let us make man to be like us and to represent us."'l

The Hebrew root of the Latin phrase for image of God-imago Deimeans image, shadow, or likeness of God. At the very least, this means humans occupy a higher place in the created order because we alone are

${ }^{1}$ Grudem, Wayne A. Systematic Theology: An Introduction to Biblical Doctrine. Grand Rapids: Zondervan, 1994. 
imprinted with god-like characteristics. Even more so, imaging God is a central aspect of our fundamental created order. To be fully human is to reflect God's creative, spiritual, intelligent, communicative, relational, moral, and purposeful characteristics. ${ }^{2}$ By realizing our gifts to their utmost potential, we are most obedient to God's design.

Human existence is a special, authoritative indicator of the creative power of God. God created man out of nothing (ex nihilo). He is a maker, an author, a creator, and a worker. We harbor an aspect of this creative ability in our capability to create something out of what God has already given us. Only God can create something out of nothing, but by forming us in his image, we can create value from and improve upon his creation. We are commanded to do nothing less. Not only do we reflect God's characteristics, but as his image-bearers, we have specific duties to fill. We are the only creatures commanded to fill the earth and subdue it, and to have dominion over all of creation (Genesis 1:28). We roam the earth with all of God's creatures, but we also rule the earth and God's creatures. God created us with the capability and the responsibility to reign over his earthly creation.

Understanding the implications of being made in the image of God is the first step. Fully appreciating the context of our creation helps foster great personal fulfillment because it brings awareness to God's intentional design of and desires for his creation.

God is unique and as image-bearers we too are unique. We bear similar characteristics, yet we are all different in talents, gifts, abilities, attitudes toward risk, subjective preferences and creative capacities. It is God's intentional design for no two humans to be the same. Our distinct uniqueness points to God's infinite power and gives us purpose. Humans are the crowning splendor of God's hand (Isaiah 62:3). Not only does God create us all differently, but he also gives each person a specific purpose. Each of us is his unique workmanship for the role he designed specifically for us to play (Ephesians 2:10). The role we have in the kingdom of God is one that no one else can occupy. Each role in the kingdom is vital. There is no role that is more important than another because God has woven all things together for his purposes-just like the

${ }^{2}$ Staub, Dick. "What Made in the Image of God Really Means." Relevant, March 4, 2013. http://www.relevantmagazine.com/god/deeper-walk/features/23549-qmadein-the-image-of-godq. 
intricate working of the human body. Paul explains this in I Corinthians 12:5-7:

There are different kinds of gifts, but the same Spirit distributes them. There are different kinds of service, but the same Lord. There are different kinds of working, but in all of them and in everyone it is the same God at work. Now to each one the manifestation of the Spirit is given for the common good.

We are made in the image of God, but we do not have the same capacity or power or holiness as God does, so we face limitations. This was true before the fall of man. We each have twenty-four hours in a day and limited means and knowledge to accomplish everything we desire. This was true before our sin, and it is true and exacerbated after our sin. Adam and Eve had to tinker and learn and think and develop skills. They were finite just as we are.

Our limitations are the reason we must come together through economic exchange if we want to make kingdom-building contributions to the common good using our creativity: we cannot do that in isolation. We will all surely perish if WE can only rely on ourselves or even a small circle of people. If we must figure out how to produce all the things we need and desire, we are left with little and so are others. However, if we, through community, have the space to cultivate and develop our skills, we can learn and improve and then are better able to serve others. That community is brought together through exchange and allows us to fulfill God's desires for his creation.

Integrated into creation is a great truth of the created universe that is often overlooked. The word that best describes God's creation is interdependence. From the very beginning, a distinct connectedness has tied all of creation together. Before sin entered the world, everything worked together in perfect harmony. Today, we still witness the interconnectedness of creation, even though it is fraught with the frustration of sin. Despite sin, we know that God is working all things together for good for those that love him and have been called according to his purpose (Romans 8:28-30). We are here to fulfill God's purposes, which he has predetermined from before the beginning of time. 


\section{Purpose And Creativity}

On the sixth day of creation, when God declared it "very good," all the necessary elements were present to work together for his purposes. There is an explicit, observable, and intentional way that all these things work together.

They function, operating in harmony, beauty, grandeur, and abundance. When God's creation works in the integrated and harmonious way in which it is intended, it points back to God and glorifies him, shalom is the result. Shalom is a word that is often translated as "peace" or the absence of conflict, but it has a much richer meaning. Shalom means universal flourishing, wholeness, and delight. It is the way things ought to be. The Old Testament prophets pictured shalom as the wolf living with the lamb, weapons turned into farming tools, deserts blooming, and the mountains streaming with red wine (Isaiah 2:4, 11:6; Ezekiel 36:35; Amos 9:13).

Each element of creation has an interconnection with all the other elements. Humans reflect something different about God's creation. We can reason, think, and decide between many alternatives. We do not strictly operate out of instinct. We are here to do much more.

God would not give us the garden and tell us to cultivate it without giving us the tools we need. In Genesis 2, God continues by giving us our marching orders and our mission. Humans have a special role in the cultivating of God's very good creation. We learn more about this in Genesis 2:15: "The Lord God took the man and put him in the Garden of Eden to work it and take care of it."

This is our mission as thinking and reasoning human beings made in God's image. We are to do two fundamental things: work his garden and take care of it. To take care of something requires putting work into it and protecting it from destruction. If God asked us just to take care of his garden, we would not alter it. One could imagine that we would stand watch and make sure it remains as is; we would preserve it. In caring for the garden, we might prune it, but we would not be "working it" in the way God asks us. The word "work" in Hebrew as used in Genesis 2:15 is the verb abad, which means "to work or to serve." 3 God explicitly asks us to work his creation and serve him. He tells us to "be fruitful and increase

3 "Strong's Hebrew: 5647. עב ד. (abad)-To Work, Serve." http://biblehub.com/ hebrew/5647.htm. 
in number; fill the earth and subdue it" (Genesis 1:28). God desires us to multiply, prosper, cultivate, and enjoy his good creation. This is our ultimate purpose, also known as the cultural mandate.

\section{SHALOM AND FLOURISHING}

With all the diversity across humanity over thousands of years, one might not expect to find many unifying ideas. Remarkably, there seems to be one meta-concept that transcends all worldviews. Jonathan Pennington writes:

This concept has staying power and universal voice because it addresses what is most basic and innate to all of humanity, despite the diversity of race, culture, and values. It is a concept that proves to be the motivating force and end goal of all that humans do and think. This idea or theme can be identified as human flourishing ... The desire for human flourishing motivates everything humans do...All human behavior, when analyzed deeply enough, will be found to be motivated by the desire for life and flourishing, individually and corporately. ${ }^{4}$

While no two humans are the same, all hearts have the same intrinsic desire. We are all created in the image of God with the desire to know him, to flourish, whether we acknowledge this or not. It is a universal truth that has been written on our hearts. It is part of our nature and our design, and as such it transcends trends and culture. Ecclesiastes 3:11 says: "He has made everything beautiful in its time. He has also set eternity in the human heart; yet no one can fathom what God has done from beginning to end."

The desire to flourish is written deep within our souls.

This idea of human flourishing is the Old Testament Hebrew concept of shalom mentioned previously. Cornelius Plantinga in his book, Not the Way It's Supposed to Be, defines shalom as: "The webbing together of God, humans, and all creation in justice, fulfillment, and delight...

\footnotetext{
${ }^{4}$ Pennington, Jonathan. "A Biblical Theology of Human Flourishing." The Institute for Faith, Work \& Economics, 2015. http://tifwe.org/resources/a-biblical-theology-ofhuman-flourishing-2/.
} 
Shalom means universal flourishing, wholeness, and delight ... the full flourishing of human life in all aspects, as God intended it to be."

One of the titles we see in the Old Testament for Christ is the Prince of Peace, but what the passage really says in Hebrew is that Jesus is the Prince of Shalom (Is. 9:6). Jesus is not just a prince that will come back and stop all the fighting; he is the prince who will come back and restore universal flourishing. His work as the Prince of Shalom "means complete reconciliation, a state of the fullest flourishing in every dimension-physical, emotional, social and spiritual." 6 The redemption brought by Christ is about restoring everything to the way it should be. Shalom bookends human existence. It characterizes the Garden of Eden (the way it was supposed to be) and the eternal City, the New Jerusalem (the way it is going to be), and so provides the vision for our existence in between. ${ }^{7}$

The word shalom is used approximately 250 times in the Hebrew Bible, with the majority of uses describing biblical flourishing. For example, shalom is the climax of the Aaronic or priestly benediction in Numbers 6:24-26, looking forward to the ultimate blessing from God: "The Lord bless you and keep you; The Lord make his face to shine upon you, and be gracious to you; The Lord lift up his countenance upon you, and give you shalom."

The work that God designed for us to do before the onset of time brings about greater levels of flourishing by advancing creation toward shalom, the way things were supposed to be. This happens despite our $\sin$ because God is at the helm of the redemptive process. Our sin does not change God's design or desire for his creation. Our sin just makes our job rife with frustration and sin.

Genesis reveals God's ultimate purposes: his glory and the flourishing of his creation. In this, our goal is stewardship (prudent cultivation) of all we are and all we have, all the time.

Stewardship comes from the Greek word oikonomia, which appears in the New Testament. It is a Greek compound word that is translated

\footnotetext{
${ }^{5}$ Plantinga, Cornelius. Not the Way It's Supposed to Be: A Breviary of Sin. Grand Rapids, MI: Eerdmans Publishing, 1995.

${ }^{6}$ Keller, Timothy. Generous Justice: How God's Grace Makes Us Just. New York, NY: Dutton, Penguin Group, 2010.

${ }^{7}$ Whelchel, Hugh. How Then Should We Work? Rediscovering the Biblical Doctrine of Work. Bloomington, IN: West Bow Press, 2012. Strong's Greek: 3622. oíкоvouía (oikonomia).
} 
as the "management of household affairs, stewardship, and administration." 8 We often think of the word stewardship as synonymous with tithing, church service, or missions. This is a narrow, insufficient understanding of stewardship. God cares about your decisions regarding all of your resources-time, money, skills. For our hearts to be fully committed to God's purpose, we must have a proper understanding of what God asks of us. God is not asking us to steward part of our income, talents, and time. He is asking us to steward all of it. The idea of wholeness is vital for stewardship; a whole-hearted commitment to God's purposes must fuel our interests and drive our daily purposes such that we are continually aligned with His desires.

Deuteronomy 6:4-5 gives us this command: "Hear, O Israel: the Lord our God, the Lord is one. Love the Lord your God with all your heart and with all your soul and with all your strength. This commandment is known as the Shema, which means "hear."

Theologian Scott Redd writes that wholeness is the goal of redemption in Christ. Redd states that the above verse is not about loving God "a lot"; it is about how our relationship with God should infiltrate every part of our lives. ${ }^{9}$ Jesus says that "where your treasure is there your heart will be also," so to be good stewards God must govern our heart, soul, and strength (Matthew 6:21). Our external choices follow.

Being good stewards, or whole-life stewards, can only come after God changes our hearts and we give our entire person to Christ. Only then can we change what we treasure. All our choices flow from our desires, so we must continually align our desires with God's desires. The social and economic order then must be buttressed by an ethos of creativity and respect for individual and property rights.

At its core, stewardship is about making choices, and making choices is the science of economics. Making decisions that please God is our goal as God's stewards. Every day, we must choose from many options, and each choice imposes a tradeoff and long-run consequences. Stewardship requires us to embrace the principles of economic thinking that stem from the principals of scripture and human anthropology.

\footnotetext{
${ }^{8}$ Stewardship, Administration. Strong's Greek: 3622. oikovo $\mu$ ía (oikonomia)—Stewardship, Administration. http://biblehub.com/greek/3622.htm.

${ }^{9}$ Redd, Scott. Wholehearted: A Biblical Look at the Greatest Commandment and Personal Wealth. McLean: The Institute for Faith, Work \& Economics, 2016.
} 


\section{OIKONOMIA: STEWARDSHIP AND THE ECONOMIC WAY OF THINKING}

Our sin, our finite knowledge, and our hubris make it difficult. We are constantly the victims of our own sin. Therefore, it is imperative to understand our origins; understanding how we got here and why we are here is critical for making God-honoring decisions. We have been given all the resources we need to accomplish what God asks of us. Now we must assess the necessary operating environment for success.

The parable of the talents is a helpful metaphor for what God asks of us as it relates to fulfilling his desires. Matthew 25:14-30 is important for our discussion about God's design and our role as whole-hearted stewards.

The passage of Matthew 25:14-30 is about maximizing productivity using our creativity for the purpose of creating more than what previously existed. The master asked each servant to take what they were given and care for it according to his desires, essentially, to invest his resources to make a profit. Greater profits of the individual level are a sign of good stewardship and increasing productivity. We are asked to do the same. Profit is about having something left over after one has invested time, talent, and treasure. Remember Genesis 1: God did not ask Adam and Eve to just watch the Garden of Eden; he told them to work it, to cultivate it, to make it better. We practice good stewardship by carefully, thoughtfully investing God's resources to make the most out of them.

We get closer to shalom in the here and now because we participate in bringing it about. We experience true joy when we do the very best we can with what we have been given. In addition, God rewards good stewardship with greater responsibility. There are spiritual and material rewards to good stewardship, both now and eternally.

We can also see from this text that what God gives us is directly related to how he uniquely crafted each of us. No two people are the same. We have different gifts and propensities that are manifested in unique ways. This means that we are all expected to steward in a wholehearted manner but that each of us brings different gifts to the table. Some have "five talents," some have one, but we are all endowed with creativity and we are expected to be put to the service of others and the common good.

When we put our creativity to use; we are then able to make positive contributions to human flourishing. This requires prudence, investment, an eye toward the future, a focus on problem-solving and a mechanism 
that fosters each one of us to look beyond a narrow view of our selfinterest to also serve others. All of this requires leftovers or residual assets. If we use up all our time, energy, and talent in the pursuit of mere survival; it is difficult perhaps impossible to have any residual to invest in others. It is only when we have something left over that we have more to give. Abundance is a good thing: not for its own sake but because it glorifies God. Abundance means that we have more than we need in one moment: more time, more energy, more nutrients, more talents. Leftovers provide the sustainable base for service, resourced generosity, and investment.

The costs of not doing this well are tragic. We suffer and become alienated from God, making things harder for both ourselves and others. It is because we are interdependent that the consequences of our actions are not isolated. They have ripple effects on others so there are social consequences when each individual person cannot or is restrained from fully using their talents. Leftovers give you additional opportunities to serve.

Without profit, we do not have extra to give. Profit is also a signal that we are doing a good job. When we have leftovers, we are accomplishing God's purposes. Profits along with lowered opportunity costs yield greater levels of wealth. What we require in a flourishing society is to have the appropriate incentives so that personal wealth is tied to advancing the social or common good. Profit is the mechanism which when pursued in a mutually inclusive way we are induced to be the best stewards possible given our constraints.

The market economy makes the profit signal the center of productive entrepreneurial activity and induces those entrepreneurs to find ways to discover new ways of doing things and to solve problems. The profit that is pursued within biblical parameters is objectively good. In Jeremiah's (Jeremiah 29:7) letter to the exiles he tells the exiles to "seek the peace and prosperity of the city to which I have carried you into exile: for if it prospers, you prosper." Biblical prosperity is mutual, it is inclusive and extends to all members of society. It is not exploitative or greedy or corrupt. All humans have the potential for this harmful behavior, but we need an environment that best allows us to seek mutual prosperity through the pursuit of monetary profit. We live in a world where this has been achieved by many nations to a large degree, it needs to be extended to everyone. 
There is a path of biblical flourishing, and material well-being is an aspect of that accomplishment. To do this, there are necessary requirements to which individuals and society must adhere. In this sense, economic realities must be respected and obeyed when we attempt to live in the social world.

\section{Economic Realities and Human Anthropology}

Economics is a science that studies human decision-making under conditions of radical uncertainty. Humans are finite and fallible; we try to maximize our own utility amid great ontological uncertainty. We pursue our own interests but that does not mean we know what to do or how to do it in the most productive manner. For this, we need to rely on the skills and talents of others. Our self-interest guides our choices but that self-interest can be used, under the right incentives and institutions, to serve others and generate greater societal well-being. To induce people to maximize their own value in a way that also maximizes the common good in the service of others we must also assess the requisite economic, political, and legal institutions that respect these realities.

The most accurate understanding of economics was eloquently explained by economist Ludwig von Mises in 1949 in his seminal work, Human Action. ${ }^{10}$ Mises defined economics as the science of purposeful human action. In our context, economics is the science of making God-pleasing decisions. If economics is about human action, what drives humans to act? Three things need to be in place for us to act with purpose: we experience a state of uneasiness, we have a vision for an improved outcome, and we take conscious and purposeful steps to get there. This does not imply that we engage in this process without error or sin, rather that we are purposeful and each of us takes the steps we deem appropriate to improve our conditions.

Mises understood the nature of man. He saw men not as preprogrammed atomistic robots but as flawed and finite individuals with purpose.

Human Action was written at an important time both in global history and inside the economics profession. The Bolshevik revolution occurred

${ }^{10}$ Mises, Ludwig von. Human Action: A Treatise on Economics. Auburn, AL: Ludwig von Mises Institute, 2008. 
in 1917 and the Soviet Union was under communist control. Simultaneously, some economists, such as Oskar Lange and Abba Lerner, were advocating for the superiority of socialism over capitalism. Later John Maynard Keynes, whose economic theory rested on the volatility and unpredictable nature of market economies, advocated for government intervention as a stabilizing mechanism. American economist Paul Samuelson maintained in his mainstream textbook Economics in 1961 that Soviet economic growth would surpass U.S. economic growth. He maintained this position until the 1980s, just pushing back the dates of the Soviet eclipse of the U.S. economy. That market socialism was considered feasible and that "persistent market failure" was mainstream belief made government management of the economy, in some shape or form, the widely held view through the twentieth century. Market socialism is embraced again today and some "managed planning" seems feasible and perhaps attractive. Today it is still attempted in varied forms either total economic planning which we see in modern Venezuela or attempts to mix some market operations with authoritarian control as in modern China.

Mises saw that even with the best of intentions, central planning disregarded vital elements of human nature and that human choice was contextually dependent. Humans were able to obtain higher levels of wealth and societal well-being under the institutional arrangements predicate upon prices, property rights, profit, and loss. Hayek demonstrated that under alternative institutional arrangements devoid of these characteristics, human immiseration persisted and poverty remained. Central planning advocates ignored the very elements that Mises understood as critical to human choice. To disprove that central planning is an appropriate economic order which could advance human flourishing, one must begin with the nature of human choice and the realities of humankind.

It is no accident that history proved Mises right, and 49 years after the release of Human Action, communism as the world saw it unfold in the Soviet Union failed. Its 71-year reign, which tried to divorce humans from their God-given purpose, killed millions and impoverished more. When we reflect on the language in Genesis and God's creation, we see that this was not his original desire for humankind but rather led to mass immiseration. The picture in Genesis before the Fall is one of abundance, both spiritually and materially. In contrast, the former Soviet Union as well as modern-day Venezuela or North Korea pitted man against himself by defying man's nature and, in its wake of horror, a godless and poor society worked hard for survival. 
Mises and F. A. Hayek fought the central planners intellectually in the twentieth century but they stood on the shoulders of those who have gone before including the sixteenth century School of Salamanca. It was their important theological contribution to the science and discipline of economics that paved the way for the future of market process theory. The sixteenth century School of Salamanca made reformulations of the concept of natural law and statements on the right to possess private property and benefit from the ownership of the private property. These theological contributions to the science of human action would be carried forward later to Carl Menger, the founder of the Austrian School of Economics. The resulting economic theory has extraordinary explanatory power because it begins with a proper understanding of human anthropology. People are purposeful in their actions; they desire something better and act to remedy their current conditions. From this, we can understand the everyday economic realities that confront us every time we engage in this calculus of choice.

The human action model proposed by Mises makes sense only because we must choose, and when we choose, we give up something else. We have unlimited desires but limited means to satisfy those desires. We must make choices, and when we choose, we face trade-offs that impose costs. The cost is always relative for each person and for each decision because we value things differently.

We live in a world of scarcity and we always have, even before the Fall, because we are finite. We have never had infinite knowledge or power. Sin exacerbated the conditions of scarcity by making everything more difficult. Human discovery, entrepreneurship, and learning are all more difficult than they were before sin. We still must choose, but those choices are less transparent and fraught with our own sinful desires.

Effective and whole-hearted stewardship requires that we are fully aware of our nature and our constraints and these are the realities of human action that can be divined from scripture and observation: scarcity, subjective value, self-interest, incentives, and interdependence.

The idea that we value things differently comes from our uniqueness. We subjectively value things based on our preferences and needs because we are all made with unique gifts and desires. Based on God's intentional design, we value things differently. Subjective value is a characteristic of all people because it is part of how God made us. We have different desires that work their way into what costs we are willing to bear to acquire 
certain things. Our varied subjective values result in many options that exist to serve a wide range of different tastes and preferences.

What we value is driven by our unique makeup, personal preferences, and our circumstances at the time. The world is better when there are more options at a lower cost. Having more options satisfies more preferences, lowers costs, and increases quality. As a result, we all profit more and have leftover resources and time to devote to other pursuits.

Subjective value drives our choices or our personal interests and preferences. It simply means that we each value things differently. There is no good or service that has objective value but rather, individuals assign values to things. Each of us assigns values differently based on our preferences. What we view to be in our self-interest is inextricably linked to what we prefer or value. The idea of self-interest can make believers recoil as it is often confused with selfishness. In some way, self-interest is a more benign concept; it is the mechanism of human choice. The Misesian human action model asserts that choice is motivated by discomfort. The subjective value determines the "terms" of choice, and we only choose things - out of self-interest-that we prefer over not having them.

When we dismiss the notion that our lives are all about God and we put ourselves first, our subjective value can become selfish, more focused on what we want, not what God wants. Consequently, things become more difficult for us. We again become victims of our own sin, and the things we think are good for us harm us. Self-interest then involves sacrifice or surrender of my will to God's will. The closer we get to God through prayer and reading his Word, the more we recognize the depth of our sin. Yet, we can still daily seek to surrender our lives to his will with every choice we make.

Self-interest is the mechanism of human action. What we perceive as "good" will orient our motives and drive our choices. We believe that we can partake in an action by choosing between alternatives and in doing so, will make ourselves better off. Because we are human, self-interest can lead to bad choices and actions, but it doesn't necessarily result in greed or coveting. Self-interest can and does involve sacrifice. It may be in one's interest to give up habits that are harmful, to work hard, and forgo leisure time, to sacrifice one's life for a family member. Greed never involves sacrifice. We need a society where greed is mitigated (not fueled by a system of incentives) and where self-interest encourages us to partake in profitmaking activities that also result in the service of others. Greed is unmitigated desire, a state of being in which one will steal, lie, cheat, and exploit 
to obtain any and possibly every whim or desire. Greed is thoughtless and harmful. It is important to remember that when ordering a society, we cannot solely concern ourselves with the incentives that ordinary people face, but the incentives that political leaders and those in power face. If we want political leaders, like those in North Korea, or China to change their behavior, we must focus on how to change the incentives they face. In the market, entrepreneurs who are both fallen and fallible are directed by the signals of profit and loss. These signals induce the entrepreneurs into activities that unleash their ideas in the service of other, ordinary people, whom they will never meet. Thus, markets do not require benevolent individuals with perfect foresight to plan economic activity but are rather guided by the interests of others in the pursuit of their own gain. These incentives guard against systemic failure because the losses, which are directed by consumers, are avoided. Prices provide these incentives and profit and loss direct behavior by serving as a feedback mechanism.

For all of this to work well, we need proper incentives. For the believer, these incentives are pleasing God. When we seek to please God in all that we do, when we ask him to be present with us in every choice, we can better steward our scarce resources for his glory, and he blesses our efforts. When we act out against God's will and his good design for us, we face frustration; we are pursuing a way the world was not meant to be. Receiving the richness of God's pleasure and blessing based on our obedient stewardship is the ultimate incentive, born out of our response to God's love and grace. Humans will not act without a motive; they must be propelled by their purposes to act. Then, when presented with choices we can reason through our alternatives and their consequences, although this process remains difficult. As the parable of the talents demonstrates, the pleasure of the master is the ultimate incentive.

The last economic and human reality we must assess is our interdependence. We are made in the image of God but are limited and finite in ways that he is not. We cannot do most things that we need to survive, and this was God's intention. God designed his people to be in community and to rely on each other's gifts and talents. Our limited nature and our diversity bring us together through trade, allowing us to thrive. I go to work and trade my time for income. I can use my income to purchase any variety of consumer goods relative to my budget. Human well-being and prosperity is advanced when I can get more for less: when housing, healthcare and food and shelter needs can all be met with better 
and better products. When those products are not solely available for consumption by the rich but across all income quintiles through the process of market competition-then we can realize a system where we can each go to work and use our gifts to serve (recall the use of the word abad in the Hebrew translation of Genesis 2:15) our fellow human beings. The extended order of the market economy also ensures that those benefits do not remain isolated or localized, but through global trade are carried across the globe. It is the extension of the market economy which is predicated on our need for trade and our desire to serve others that has lifted the masses out of poverty at exceedingly high rates. World poverty has been cut by $36 \%$ since 1990 and the world poverty rates continue to fall at rapid rates. Today for the first time in human history, the global abject poverty rate (those living under $\$ 1.90$ per day) is less than $10 \%$.

It is global trade and widening circles of exchange that has allowed this to happen. Trade includes those who have been excluded. It gives them access to goods and services that they formerly went without or obtained on their own. Trade fostered by market entrepreneurship is inclusive and extends its benefits in egalitarian ways, as evidenced by the rapid decline in poverty. This system of trade is essential for flourishing, and it is only made possible when we can depend on each other. Trading based upon on subjective value allows us to be free to do what God created us to do. We don't have to figure it all out because we were not made to do everything. Only God can do that.

Trade allows us to profit in our time while lowering all our costs. As we discussed, when we make a choice, we always bear a cost. The cost is the forgone opportunity at that moment in time, known as the opportunity cost. Trade brings strangers together to serve each other. For this to work well, we need a society that embraces the biblical principles of peaceful cooperation. Markets are an important aspect of that society buttressed by limited and peaceful government, extended cooperative international relationships, the rule of law and a robust civil society empowered by religious freedom, political freedom and economic freedom.

An extended cooperative and prosperous social order requires a market-based society predicated on property rights, profit and loss, prices, and the rule of law. Property rights are a necessary incentive for trade. Property rights also provide the basis for the emergence of prices. As prices fluctuate, they help us evaluate what we want based on our subjective values. Prices change based on changing scarcity levels and when they do, we reevaluate each choice, all in the pursuit of profit. Property 
rights give us boundaries, establish and protect our ownership rights, and provide a basis for trade.

Prices also help us seek profit and avoid losses personally and in our business ventures. When someone brings a product to the market, they seek to make money and have residual resources left over. Profits and losses are levied by consumers. The products and services available to us are only available if they are profitable. They are only profitable if they serve the needs of the consumer in some way. Profitable products and services free consumers from figuring out how to do those things on their own. Prices then provide information that we could never acquire on our own. Where prices exist, we are already better off than we would be without them; we have a benchmark to evaluate trade-offs and economize on our time.

This complex system of trade requires the rule of law. The rule of law means that everyone is treated equally before the law, that the law is transparent, laid out in advance, and that the leaders must submit themselves to it. The rule of law prohibits arbitrary behavior on behalf of rulers and allows for predictable behavior on behalf of everyone.

F. A. Hayek, in his famous book The Road to Serfdom, warned that as the state plans more of people's lives, we begin to shred the rule of law. ${ }^{\text {ll }}$ As a state takes over more economic activity, society converts into a law of specific and exclusive rules rather than the rule of law. There is debate in the economic literature regarding how much government intervention in an economy leads to such disastrous results and certainly most of the world lives in what we would deem "mixed economies." For Hayek, and for our consideration, the relevant question is the role of government as it pertains to human flourishing. Beyond that role, the quintessential question of political economy is how to constrain the state from growing larger and dominating more of the private sector. Leaders will start to change the rules to suit their will rather than submit their arbitrary whims of power to a preexisting set of rules. This happens precisely because the state does not have any idea how to order economic affairs. They don't know what types of products various consumers want nor could they fully comprehend the production process and the relative trade-offs to understand how to bring goods to consumers. Nor do they have the incentives (profit and loss) to learn how to bring these items to the consumers that

${ }^{11}$ Hayek, Friedrich A. von and Bruce Caldwell. The Road to Serfdom: Text and Documents. Chicago: University of Chicago Press, 2007. 
need and want them at the lowest possible cost (the hallmark of prudence and stewardship).

Without the rule of law, we lose predictability of state behavior. One cannot have confidence that state agents will not break into their property and steal all of their possessions. The rule of law limits the state's ability to plunder and to infringe on our ability to choose as God directs us. When we live in a society with the rule of law, we can make plans, for living out God's desires in our life. If God is calling you to open a business or a church, property rights and rule of law will make that much easier. You can raise money for investments in buildings and businesses. The rule of law is essential for well-protected, well-defined, and transferable property rights. In early Christianity the rule of law was not broadly operationalized in society so not everyone benefitted from the benefits of well-protected property that applied equally to all in society. Society loses when property rights and protections are not established with generality and accessibility to all citizens.

When we have property rights and the rule of law combined with political, religious, and economic freedom, ${ }^{12}$ we can pursue God's purposes as they pertain to our unique lives. When any of these three freedoms are limited, we are less free to be wholehearted stewards.

\section{CONCLUSION}

We must understand God's purposes for life as he wishes and be the best stewards we can with what he has given us both individually and collectively. We are designed to live among each other and serve each other. We never were designed for atomistic individualism. When we can order society in a way that allows us to rely on each other, to embrace our interdependence, then we have the best chance, through our work to serve one another and make lasting contributions to human flourishing and in doing so help each other and glorify God.

We require an[d] extended social, economic, and political order that allows each person, created with dignity, to unleash their human creativity as God leads them. This necessitates a market economy where dispersed individuals can discover, learn, and through the system of profits and losses can find ways to serve one another. When society is predicated

${ }^{12}$ Gwartney, James, Robert Lawson, and Joshua Hall. Economic Freedom Dataset. Report. Frasier Institute, 2015. http://www.freethe-world.com/datasets_efw.html. 
on these realities of human nature and scarcity of resources it is best positioned to make kingdom-building advances to human flourishing. All of this suggests that there is a path to prosperity and a path that pushes societies away from prosperity. When societies are ordered in ways that ignore human nature and try to order economies from the top-down, immiseration follows as is evidenced by the devastation of centrally planned economies in the twentieth century including but not limited to: Mao's China, Stalin and Lenin's Soviet Union, the Khmer Rouge in Cambodia, and Tito's Yugoslavia. ${ }^{13}$ This phenomenon is not a historical artifact or dated history that somehow, we have overcome. Today's Venezuela ${ }^{14}$ and North Korea provide extreme examples of twenty-first-century experiments with top-down planning-they lead to human misery and diminish the capacity for ordinary people to provide for their families and communities-people are forced inward to merely focus on survival and many do not.

But what about modern-day China? China in just 40 years with limited economic reforms has lifted almost 800 million of its citizens out of abject poverty. ${ }^{15}$ China has gained economic freedom since the late 1970s and now is a place where global corporations flock to open manufacturing plants which provide jobs and opportunities for those who very recently were destined to subsistence farming. The extension of global markets to China is allowing the Chinese to experience their own Industrial Revolution in a much shorter time that the West first experienced it. These are good things and they include in global markets people who were forever excluded. But can China maintain a mixed economic and political strategy of limited market economies and authoritarian political control? It remains to be seen what the future will be for China. Now it is characterized by the World Bank as an upper-middle-income country that is transitioning to a market economy. ${ }^{16}$ This is the greatest hope China

${ }^{13}$ Rummel, R. J. Death by Government: Genocide and Mass Murder Since 1900. Routledge, 5th Printing Edition, 1997.

${ }^{14}$ Today, Venezuela ranks last in the world in Economic Freedom and is expected to experience an inflation rate of one million percent. Mass emigration, rioting and empty shelves are the norm. The government continues to vie for control and pacify the population, it's latest attempt with yet another minimum wage hike. None of this has helped the economy or it's people.

15 The World Bank in China. http://www.worldbank.org/en/country/china/overview. ${ }^{16}$ Ibid. 
has ever had for sustainable human flourishing characterized by personal liberty, but China isn't there yet. It is quite possible that advances in economic freedom that have already been obtained will pave the way for more economic freedom and political freedom, but there is no guarantee. Milton Friedman and F. A. Hayek hypothesized, which is supported empirically, that economic freedom is a necessary but not sufficient condition for political freedom. ${ }^{17}$ Meaning a free market economy is a necessary but not sufficient condition for a country to transition to one of liberal democracy and limited government.

China could easily lapse back into a fully planned economy and with it will lose the precious gains its citizens have obtained. When political leaders attempt to "design" society in a way that they think will benefit them the most, economic failure most often results. There is a path to prosperity and it requires a market economy which best, although not perfectly, allows for maximizing biblical human flourishing. The ethos of freedom, human agency, property rights, service, and the common good must be at the core of any economic order and then the incentives must follow. This is the path for stewardship.

\section{BIBLIOGRAPHY}

Grudem, Wayne A. Systematic Theology: An Introduction to Biblical Doctrine. Grand Rapids: Zondervan, 1994.

Gwartney, James, Robert Lawson, and Joshua Hall. Economic Freedom Dataset. Report. Frasier Institute, 2015. http://www.freethe-world.com/datasets_efw. html.

Hayek, Friedrich A. von, and Bruce Caldwell. The Road to Serfdom: Text and Documents. Chicago: University of Chicago Press, 2007.

Keller, Timothy. Generous Justice: How God's Grace Makes Us Just. New York, NY: Dutton, Penguin Group, 2010.

Lawson, Robert A., and Jeff Clark. "Examining the Hayek-Friedman Hypothesis on Economic and Political Freedom." Journal on Economic Behavior and Organization, 74, no. 3 (2010): 230-239.

Mises, Ludwig von. Human Action: A Treatise on Economics. Auburn, AL: Ludwig von Mises Institute, 2008.

${ }^{17}$ Lawson, Robert A. and Jeff Clark. "Examining the Hayek-Friedman Hypothesis on Economic and Political Freedom." Journal on Economic Behavior and Organization, Vol. 74, Issue 3, 2010, pp. 230-239. 
Pennington, Jonathan. "A Biblical Theology of Human Flourishing." The Institute for Faith, Work \& Economics, 2015. http://tifwe.org/resources/abiblical-theology-of-human-flourishing- $2 /$.

Plantinga, Cornelius. Not the Way It's Supposed to Be: A Breviary of Sin. Grand Rapids, MI: Eerdmans Publishing, 1995.

Redd, Scott. Wholehearted: A Biblical Look at the Greatest Commandment and Personal Wealth. McLean: The Institute for Faith, Work \& Economics, 2016.

Rummel, R. J. Death by Government: Genocide and Mass Murder Since 1900. London: Routledge, 5th Printing Edition, 1997.

Staub, Dick. "What Made in the Image of God Really Means." Relevant, March 4, 2013. http://www.relevantmagazine.com/god/deeper-walk/ features/23549-qmade-in-the-image-of-godq.

Whelchel, Hugh. How Then Should We Work? Rediscovering the Biblical Doctrine of Work. Bloomington, IN: WestBow Press, 2012.

Open Access This chapter is licensed under the terms of the Creative Commons Attribution 4.0 International License (http://creativecommons.org/licenses/ by $/ 4.0 /)$, which permits use, sharing, adaptation, distribution and reproduction in any medium or format, as long as you give appropriate credit to the original author(s) and the source, provide a link to the Creative Commons license and indicate if changes were made.

The images or other third party material in this chapter are included in the chapter's Creative Commons license, unless indicated otherwise in a credit line to the material. If material is not included in the chapter's Creative Commons license and your intended use is not permitted by statutory regulation or exceeds the permitted use, you will need to obtain permission directly from the copyright holder.

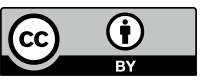

